\title{
Identifying Uniform Core Journal Titles for Music Libraries: A Dissertation Citation Study
}

\section{Lois Kuyper-Rushing}

In an attempt to create a new tool to aid librarians in choosing music journals, citations from music dissertation bibliographies submitted in 1993 from across the United States were gathered and analyzed. Core lists of journals were developed and then compared to lists compiled by analyzing doctoral dissertation bibliographies in the field of music from a single institution. The journal lists from a national study differed from those derived from the study of journals used at a single institution. Also, newly published journals are used regularly by doctoral students in music, and several are on the lists of core journals compiled.

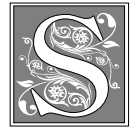

piraling subscription costs have forced libraries to review existing journal subscriptions, to cancel titles deemed least essential by faculty, students, and other users, and to add new subscriptions when necessary and feasible. Most librarians agree that no single method of evaluation should be used when making such collection management decisions. Citation studies, in concert with user surveys and other tools, ensure that the decision-making process is balanced and effective. In addition to providing excellent collection assessment data, citation studies can identify titles that are core to a collection and those that are essential to specific areas of study.

Investigators have been publishing the results of citation studies for years. Authors have approached the citation study with a variety of goals. Two studies conducted by Tina E. Chrzastowski and Karen A. Schmidt ${ }^{1,2}$ tracked serial cancellations to determine at-risk journals in academic libraries. Other studies have been conducted to identify factors associated with the value of a journal in promotion and tenure decisions ${ }^{3}$ and to measure faculty publishing productivity. ${ }^{4}$

In several previous studies, the bibliographies of dissertations produced at a single institution have been analyzed to determine core journals in a specific field for the specific university. This study departs from the usual single-institution study by tabulating and analyzing the bibliographies of music dissertations from universities throughout the United States.

This investigator focused on developing measurement data that could serve as a model for other music libraries. Examining dissertations at a single institution to formulate a core list of journals provides valuable information. Having a core list of journals determined by a national study to which the university's list can be compared will prove instructive and helpful to the bibliographer. Identifying a uniform core of journals cited by music researchers throughout the United States

Lois Kuyper-Rushing is Head of Music Resources at Louisiana State University; e-mail: lkuper@lsu.edu. 
TABLE 1

Citation Counts of All Degrees in Ranked Order of Frequency

\begin{tabular}{lccc}
\hline \hline & $\begin{array}{c}\text { No. of } \\
\text { Citations }\end{array}$ & $\begin{array}{c}\text { \% of Total } \\
\text { Citations }\end{array}$ & $\begin{array}{c}\text { Cumulative } \\
\text { of Citations }\end{array}$ \\
Journal & 137 & 3.60 & 3.60 \\
\hline Perspectives of New Music & 121 & 3.18 & 6.78 \\
Journal of Research In Music Education & 110 & 2.89 & 9.67 \\
Musical Quarterly & 92 & 2.42 & 12.09 \\
Music Educator's Journal & 79 & 2.08 & 14.17 \\
Journal of Music Theory & 78 & 2.05 & 16.22 \\
Journal of the American Musicological Society & 65 & 1.71 & 17.92 \\
Music Theory Spectrum & 59 & 1.55 & 19.47 \\
Computer Music Journal & 57 & 1.50 & 20.97 \\
Instrumentalist & 46 & 1.21 & 22.18 \\
In Theory Only & 45 & 1.18 & 23.36 \\
Bulletin of the Council of Research on & & & \\
$\quad$ Music Education & 44 & 1.16 & 24.52 \\
Nineteenth Century Music & 41 & 1.08 & 25.60 \\
Music and Letters & 41 & 1.08 & 26.68 \\
Psychology of Music & 37 & 0.97 & 27.65 \\
Music Analysis & 36 & 0.95 & 28.59 \\
Music Perception & 36 & 0.95 & 29.54 \\
Musical Times & 34 & 0.89 & 30.43 \\
Journal of Teacher Education & 33 & 0.87 & 31.30 \\
Journal of Music Therapy & 33 & 0.87 & 32.17 \\
Music Review & 30 & 0.79 & 32.96 \\
Clavier & 30 & 0.79 & 33.75 \\
Interface & 29 & 0.76 & 34.51 \\
Perception and Psychophysics & 27 & 0.71 & 35.22 \\
Ethnomusicology & 27 & 0.71 & 35.93 \\
Journal of Aesthetic Education & 27 & 0.71 & 36.64 \\
Journal of Experimental Psychology & & & \\
& & & \\
\end{tabular}

provides another reliable measurement system for evaluating collections.

\section{Literature Review}

Most citation studies have focused on the sciences, ${ }^{5}$ perhaps because scientific research depends on the currency of information available in journal literature more than humanities or social science research does. Moreover, scientists often use the frequency of citations to an article to gauge its value and impact on other researchers, a factor that frequently plays a role in making tenure and promotion decisions. Another reason could well be the high costs of scientific journal subscriptions. The results of science citation studies have been useful in identifying core journals in the sciences.
Although most citation studies have focused on scientific journal collections, a number have been performed in the humanities as well. In 1975, Lois Bebout, Donald Davis Jr., and Donald Oehlerts reported that citation studies in the humanities had been conducted since 1948 in American literature, speech, philology, music, and the fine arts. ${ }^{6}$ More recent humanities citation studies are available in the fields of German literature, American literature, history, philosophy, and music. $^{7-11}$

Several citation studies have focused solely on dissertation bibliographies and were used to formulate a "core list" of journals for a specific discipline. Articles concerning dissertations by students in various fields have been published, in- 


\begin{tabular}{|c|c|c|c|}
\hline \multicolumn{4}{|c|}{$\begin{array}{l}\text { TABLE 1(cont.) } \\
\text { Citation Counts of All Degrees in Ranked Order of Frequency } \\
\end{array}$} \\
\hline$\underline{\text { Journal }}$ & $\begin{array}{c}\text { No. of } \\
\text { Citations }\end{array}$ & $\begin{array}{l}\% \text { of Total } \\
\text { Citations }\end{array}$ & $\begin{array}{c}\text { Cumulative \% } \\
\text { of Citations }\end{array}$ \\
\hline Musical America & 26 & 0.68 & 37.32 \\
\hline Journal of Band Research & 25 & 0.66 & 37.98 \\
\hline Medical Problems of Performing Artists & 25 & 0.66 & 38.63 \\
\hline Psychological Review & 25 & 0.66 & 39.29 \\
\hline Musical Courier & 23 & 0.60 & 39.89 \\
\hline Journal of Musicology & 22 & 0.58 & 40.47 \\
\hline Etude & 21 & 0.55 & 41.02 \\
\hline Action in Teacher Education & 20 & 0.53 & 41.55 \\
\hline American Music Teacher & 20 & 0.53 & 42.08 \\
\hline NATS Bulletin & 20 & 0.53 & 42.60 \\
\hline Teтро & 20 & 0.53 & 43.13 \\
\hline Acta Musicologica & 19 & 0.50 & 43.63 \\
\hline Archiv für Musikwissenschaft & 19 & 0.50 & 44.13 \\
\hline Choral Journal & 19 & 0.50 & 44.63 \\
\hline Journal of the Arnold Schoenberg Inst. & 18 & 0.47 & 45.10 \\
\hline Educational Technology & 17 & 0.45 & 45.55 \\
\hline Journal of Aesthetics and Art Criticism & 17 & 0.45 & 45.99 \\
\hline Journal of Research in Singing & 17 & 0.45 & 46.44 \\
\hline New York Times & 16 & 0.42 & 46.86 \\
\hline Psychomusicology & 16 & 0.42 & 47.28 \\
\hline Theory into Practice & 16 & 0.42 & 47.70 \\
\hline$M I X$ & 15 & 0.39 & 48.09 \\
\hline Music Journal & 15 & 0.39 & 48.49 \\
\hline Canadian Music Educator's Journal & 14 & 0.37 & 48.86 \\
\hline Early Music & 14 & 0.37 & 49.22 \\
\hline Journal of the Acoustical Soc. of America & 14 & 0.37 & 49.59 \\
\hline Notes & 14 & 0.37 & 49.96 \\
\hline
\end{tabular}

cluding music (1983), philosophy (1991), psychology (1995), and political science (1994). ${ }^{12-15}$ Each of these authors studied the dissertations found in a single institution in a broad field. The citations to journals were counted, and lists of core journals were developed.

\section{Purpose of the Study}

Using information resulting from the study of dissertation bibliographies graduates of music doctoral programs across the United States in 1993, several questions can be addressed that provide useful data on music collection management. This study focuses on addressing the following:

- What journals have the highest usage in music dissertations generally and in the subcategories of music (e.g., musicology, music education, performance, and applied music) ${ }^{16}$

- How frequently are materials in formats other than books and serials being used in music dissertations?

- How do national data compare to data gathered for a single institution?

The information collected and analyzed in response to these questions can provide music librarians and researchers throughout the United States with data critical to measuring the relevancy of their collections for doctoral research.

\section{Procedure}

This investigation was initiated by creating a file of the 474 music dissertations listed in Dissertation Abstracts for degrees 
TABLE 2

Citation Counts in Ranked Order of Frequency in Musicology Dissertations

\begin{tabular}{lccc} 
& $\begin{array}{c}\text { No. of } \\
\text { Citations }\end{array}$ & $\begin{array}{c}\text { \% of Total } \\
\text { Citations }\end{array}$ & $\begin{array}{c}\text { Cumulative \% } \\
\text { of Citations }\end{array}$ \\
\hline Journal & 24 & 4.15 & 4.15 \\
Journal of the American Musicological Society & 12 & 2.07 & 6.22 \\
Nineteenth Century Music & 11 & 1.90 & 8.12 \\
Archiv für Musikwissenschaft & 11 & 1.90 & 10.02 \\
Village Voice & 10 & 1.73 & 11.74 \\
Acta Musicologica & 10 & 1.73 & 13.47 \\
Church News & 10 & 1.73 & 15.20 \\
Music and Letters & 9 & 1.55 & 16.75 \\
Musica Disciplina & 8 & 1.38 & 18.13 \\
Medical Problems of Performing Artists & 8 & 1.38 & 19.52 \\
Second Line & 7 & 1.21 & 20.73 \\
American-German Review & 7 & 1.21 & 21.93 \\
Black Music Research Journal & 7 & 1.21 & 23.14 \\
Music Analysis & 6 & 1.04 & 24.18 \\
Black Perspective in Music & 6 & 1.04 & 25.22 \\
Journal of the Historical Society of the & & & \\
$\quad$ Cocalico Valley & 6 & 1.04 & 26.25 \\
Musical Times & 6 & 1.04 & 27.29 \\
Revista Italiana di Musicologica & 6 & 1.04 & 28.32 \\
Studi verdiani & 5 & 0.86 & 29.19 \\
Cambridge Opera Journal & 5 & 0.86 & 30.05 \\
Chambersburg Record Herald & 5 & 0.86 & 30.92 \\
Lancaster County Historical Society: & 5 & 0.69 & 34.20 \\
$\quad$ Papers and Addresses & 5 & 0.86 & 31.78 \\
Music Review & 5 & 0.86 & 32.64 \\
Musical Quarterly & 5 & 0.86 & 33.51 \\
Pennsylvania Magazine of History and Biography & 4 & &
\end{tabular}

awarded in 1993 from Carnegie I research institutions, using a keyword search for "music" and the date of 1993. The year 1993 was chosen because later years were not yet complete in the Dissertation Abstracts database when the study began. Each of the 474 authors found in Dissertation Abstracts was searched in the $1997 \mathrm{Na}$ tional Faculty Directory. Of that total, 181 authors were found in the Directory and a written request was sent to each asking for copy of the bibliography from his or her dissertation. The graduates identified for this pool were considered academically most successful in 1993 because they already had begun their careers as members of university faculties before or soon after being awarded the degree. This method of selection was used to reduce the pool and provide a more manageable number of references. The dissertation bibliographies not returned by the authors were obtained from other libraries via interlibrary loan. A total of 118 usable bibliographies was collected, constituting 25 percent of the total 1993 dissertations and 65 percent of the pool deemed successful because of their immediate employment. ${ }^{17}$

Each dissertation was identified in one of the subdisciplines listed: musicology, music theory, music education, applied music, ethnomusicology, conducting, music therapy, and piano pedagogy. Whenever possible, the dissertation author identified his or her subcategory in music, either on an attached form or in response to a personal query. In some instances, the title page of the dissertation 


\begin{tabular}{|c|c|c|c|}
\hline \multicolumn{4}{|c|}{$\begin{array}{c}\text { TABLE } 2 \text { (cont.) } \\
\text { Citation Counts in Ranked Order of Frequency in Musicology Dissertations } \\
\end{array}$} \\
\hline Journal & $\begin{array}{c}\text { No. of } \\
\text { Citations }\end{array}$ & $\begin{array}{c}\% \text { of Total } \\
\text { Citations }\end{array}$ & $\begin{array}{c}\text { Cumulative } \% \\
\text { of Citations }\end{array}$ \\
\hline Archivio storico lombardo & 4 & 0.69 & 34.89 \\
\hline Chicago Defender & 4 & 0.69 & 35.58 \\
\hline Ear & 4 & 0.69 & 36.27 \\
\hline Eberbacher Geschichtsblatt & 4 & 0.69 & 36.96 \\
\hline Footnote & 4 & 0.69 & 37.65 \\
\hline High Fidelity and Musical America & 4 & 0.69 & 38.34 \\
\hline Music Educator's Journal & 4 & 0.69 & 39.03 \\
\hline Perspectives of New Music & 4 & 0.69 & 39.72 \\
\hline Revue de Musicologie & 4 & 0.69 & 40.41 \\
\hline Antiques & 3 & 0.52 & 40.93 \\
\hline Art Bulletin & 3 & 0.52 & 41.45 \\
\hline Chronicon & 3 & 0.52 & 41.97 \\
\hline Die Musikforschung & 3 & 0.52 & 42.49 \\
\hline Downbeat & 3 & 0.52 & 43.01 \\
\hline Early Music History & 3 & 0.52 & 43.52 \\
\hline Godey's Lady's Book & 3 & 0.52 & 44.04 \\
\hline Journal of Music Theory & 3 & 0.52 & 44.56 \\
\hline Journal of Research in Music & 3 & 0.52 & 45.08 \\
\hline Musician & 3 & 0.52 & 45.60 \\
\hline New York Times & 3 & 0.52 & 46.11 \\
\hline Pennsylvania Mennonite Heritage & 3 & 0.52 & 46.63 \\
\hline Proceedings of the Royal Musical Assoc. & 3 & 0.52 & 47.15 \\
\hline Rhythm & 3 & 0.52 & 47.67 \\
\hline $\begin{array}{l}\text { Sammelbande der Internationalen } \\
\text { Musik-Gesellschaft }\end{array}$ & 3 & 0.52 & 48.19 \\
\hline
\end{tabular}

indicated the area of music in which the author had obtained his or her degree. For the rest, the discipline was assigned according to the subject matter of the dissertation.

\section{Results}

\section{Journals with the Highest Usage}

Some of the most useful results of a citation study are the lists of journals cited. The first of these in the present study is a list of journals used by doctoral students in all music disciplines, listed in order of frequency of use. Table 1 shows fifty-three journals that were cited most often by doctoral students.

Tables 2 through 5 provide ranked frequency of citations of journals within the various disciplines of music. Journals whose citations made up the top 50 percent were included in these tables. Dissertations were identified as being in the fields of musicology, music theory, music education, applied music, conducting, ethnomusicology, music therapy, and piano pedagogy. Lists are given for musicology, music theory, music education, and applied music. Ethnomusicology, music therapy, conducting, and piano pedagogy each had so few graduates in this survey group that the lists are not statistically valid. Of the 118 dissertations gathered, 16 were in musicology, 16 in music theory, 32 in music education, and 40 in applied music.

The preponderance of citations from nonmusic journals used in music educa- 


\begin{tabular}{|c|c|c|c|}
\hline \multicolumn{4}{|c|}{$\begin{array}{c}\text { TABLE } 3 \\
\text { Citation Counts in Ranked Order of Frequency in Music } \\
\text { Theory Dissertations } \\
\end{array}$} \\
\hline Journal & $\begin{array}{c}\text { No. of } \\
\text { Citations }\end{array}$ & $\begin{array}{c}\% \text { of Total } \\
\text { Citations }\end{array}$ & $\begin{array}{c}\text { Cumulative } \% \\
\text { of Citations }\end{array}$ \\
\hline Perspectives of New Music & 128 & 12.55 & 12.55 \\
\hline Journal of Music Theory & 80 & 7.84 & 20.39 \\
\hline Music Theory Spectrum & 62 & 6.08 & 26.47 \\
\hline Computer Music Journal & 56 & 5.49 & 31.96 \\
\hline In Theory Only & 46 & 4.51 & 36.47 \\
\hline Musical Quarterly & 40 & 3.92 & 40.39 \\
\hline Music Perception & 31 & 3.04 & 43.43 \\
\hline Interface & 29 & 2.84 & 46.27 \\
\hline Music Analysis & 27 & 2.65 & 48.92 \\
\hline
\end{tabular}

tion dissertations (50\%) may be attributed to the interdisciplinary characteristic of the field. The nonmusic journals seen in the music education list (table 4) are in the fields of education or psychology.

\section{Various Formats Used in Music Disserta- tions}

The 118 dissertation bibliographies produced 13,111 citations. When the citations were examined by format, a profile emerged. Books constituted 41 percent of the citations and serials 29 percent, with a variety of other formats constituting the total. The types of materials and the percentages of each can be seen in table 6 .

Although the percentages of books and serials used by the various disciplines within music vary widely, most of the subdisciplines depend more heavily on books than on serials. The only exception in this study was music therapy, and the number of authors in this category is too small to draw any valid conclusions. This finding provides a small measure of comfort to librarians who have been forced

\begin{tabular}{|c|c|c|c|}
\hline \multicolumn{4}{|c|}{$\begin{array}{c}\text { TABLE } 4 \\
\text { Citation Counts in Ranked Order of Frequency in Music Education } \\
\text { Dissertations }\end{array}$} \\
\hline Journal & $\begin{array}{l}\text { No. of } \\
\text { Citations }\end{array}$ & $\begin{array}{l}\% \text { of Total } \\
\text { Citations }\end{array}$ & $\begin{array}{c}\text { Cumulative \% } \\
\text { of Citations }\end{array}$ \\
\hline Journal of Research In Music Education & 101 & 10.39 & 10.39 \\
\hline Music Educator's Journal & 78 & 8.02 & 18.42 \\
\hline $\begin{array}{l}\text { Bulletin of the Council } \\
\quad \text { for Research in Music Ed. }\end{array}$ & 42 & 4.32 & 22.74 \\
\hline Instrumentalist & 37 & 3.81 & 26.54 \\
\hline Journal of Teacher Education & 34 & 3.50 & 30.04 \\
\hline Psychology of Music & 34 & 3.50 & 33.54 \\
\hline Journal of Aesthetic Education & 27 & 2.78 & 36.32 \\
\hline Action in Teacher Education & 20 & 2.06 & 38.37 \\
\hline Educational Technology & 20 & 2.06 & 40.43 \\
\hline Journal of Experimental Psychology & 20 & 2.06 & 42.49 \\
\hline Psychological Review & 20 & 2.06 & 44.55 \\
\hline Journal of Band Research & 17 & 1.75 & 46.30 \\
\hline Perception and Psychophysics & 16 & 1.65 & 47.94 \\
\hline MIX & 15 & 1.54 & 49.49 \\
\hline
\end{tabular}




\begin{tabular}{|c|c|c|c|}
\hline \multicolumn{4}{|c|}{$\begin{array}{c}\text { TABLE } 5 \\
\text { Citation Counts in Ranked Order of Frequency in } \\
\text { Applied Music Dissertations }\end{array}$} \\
\hline Journal & $\begin{array}{c}\text { No. of } \\
\text { Citations }\end{array}$ & $\begin{array}{c}\% \text { of Total } \\
\text { Citations }\end{array}$ & $\begin{array}{c}\text { Cumulative \% } \\
\text { of Citations }\end{array}$ \\
\hline Musical Quarterly & 54 & 6.38 & 6.38 \\
\hline Journal of the American Musicological Society & 31 & 3.66 & 10.04 \\
\hline Musical Times & 25 & 2.95 & 12.99 \\
\hline Musical Courier & 23 & 2.72 & 15.70 \\
\hline Musical America & 22 & 2.60 & 18.30 \\
\hline NATS Bulletin & 21 & 2.48 & 20.78 \\
\hline Etude & 19 & 2.24 & 23.02 \\
\hline Clavier & 17 & 2.01 & 25.03 \\
\hline Journal of Research in Singing & 17 & 2.01 & 27.04 \\
\hline Music and Letters & 17 & 2.01 & 29.04 \\
\hline Musical Opinion & 16 & 1.89 & 30.93 \\
\hline American Music Teacher & 12 & 1.42 & 32.35 \\
\hline Music Review & 12 & 1.42 & 33.77 \\
\hline Tempo & 12 & 1.42 & 35.18 \\
\hline Journal of the Acoustical Society of America & 11 & 1.30 & 36.48 \\
\hline Early Music & 9 & 1.06 & 37.54 \\
\hline International Trombone Assoc. Journal & 9 & 1.06 & 38.61 \\
\hline Music Educator's Journal & 9 & 1.06 & 39.67 \\
\hline Music Journal & 9 & 1.06 & 40.73 \\
\hline New York Times & 9 & 1.06 & 41.79 \\
\hline Notes & 9 & 1.06 & 42.86 \\
\hline Choral Journal & 8 & 0.94 & 43.80 \\
\hline Folia Phoniatrica & 8 & 0.94 & 44.75 \\
\hline Journal of Musicology & 8 & 0.94 & 45.69 \\
\hline Schweizerische Musikzeitung & 8 & 0.94 & 46.64 \\
\hline American Organist & 7 & 0.83 & 47.46 \\
\hline Fanfare & 7 & 0.83 & 48.29 \\
\hline High Fidelity/Musical America & 7 & 0.83 & 49.11 \\
\hline Journal of Research in Music Educations & 7 & 0.83 & 49.94 \\
\hline Neue Zeitschrift für Musik & 7 & 0.83 & 50.77 \\
\hline Osterreichische Musikzeitschrift & 7 & 0.83 & 51.59 \\
\hline Piano Quarterly & 7 & 0.83 & 52.42 \\
\hline Soundboard & 7 & 0.83 & 53.25 \\
\hline
\end{tabular}

to cancel journal subscriptions and have concentrated on monograph purchases!

From table 6, it can be seen that books and serials, the most common formats used in all scholarly research, are more heavily used by music researchers than materials in all other formats combined. This is surprising only when one notes that the use of scores and sound record- ings constitutes a total of only 4 percent of all citations. If manuscript and original source materials are added, which include music as well as other types of manuscript materials, the total rises to a mere 9 percent of the total citations. Because these are dissertations in the field of music, one might assume that published, recorded, or manuscript music 


\begin{tabular}{|c|c|c|}
\hline \multicolumn{3}{|c|}{$\begin{array}{c}\text { TABLE } 6 \\
\text { Citation Counts by Format in Music } \\
\text { Dissertations } \\
\end{array}$} \\
\hline Format & Citations & $\begin{array}{l}\% \text { of } \\
\text { total }\end{array}$ \\
\hline Books & 5,375 & 41 \\
\hline Serials & 3,805 & 29 \\
\hline \multicolumn{3}{|l|}{ Other: } \\
\hline $\begin{array}{l}\text { Dissertation and } \\
\text { Dissertation } \\
\text { Abstract citations }\end{array}$ & 814 & 6 \\
\hline Reference materials & 746 & 6 \\
\hline $\begin{array}{l}\text { Manuscripts/Original } \\
\text { source materials }\end{array}$ & 701 & 5 \\
\hline Scores & 465 & 4 \\
\hline Sound recordings & 134 & 1 \\
\hline Miscellaneous & 1,071 & 8 \\
\hline Subtotal & 3,931 & 30 \\
\hline Total & 13,111 & $100 \%$ \\
\hline
\end{tabular}

would provide a higher percentage of citations, but according to this study, that assumption is false.

Table 7 provides a profile of the usage of books and periodicals in each of the disciplines of music. In 1983, Richard Griscom published a citation study of theses and dissertations in music at Indiana University. ${ }^{18} \mathrm{He}$ included information similar to that found in table 7 . The overwhelming difference between this part of his study and the present study is the number of citations per source document. In the four areas of concentration that Griscom identified (music theory, music education, musicology, and applied music), the overall average number of citations per source document was fiftyseven, whereas in the present study it was 111. This could be due to the inclusion of master's theses in the Griscom study or a predilection toward fewer citations at the university studied by Griscom, but it also could point to a higher reliance on cited materials in current dissertation literature.

Table 7 indicates that, with the exception of music therapy, a higher percentage of books than periodicals was used in every music discipline. ${ }^{19}$ This finding is similar to Griscom's results in which the overall ratio of book citations to peri- odical citations was 1.9 to 1 , compared to the present study in which the ratio was 1.4 to $1 .^{20}$ In John Budd's study of American literature publications, the ratio of books to journals was even greater-2.4 to $1 .{ }^{21}$ Any number of authors echo Katherine W. McCain's assertion that: "Throughout the range of studies of information needs and information use in humanities research . . . , humanities scholarship is characterized as individualist [and] highly dependent on monographs (as opposed to journals) as sources ...." 22

\section{How National Data Compare with Local Data}

In his 1983 article, Griscom published a core list of journals for music in general and in the areas of musicology, music theory, and music education at Indiana University. ${ }^{23}$ The lists from his study and those compiled in the present study were compared, noting the overlap between the titles on both lists from which 50 percent of all citations were taken. For the purpose of discussion, the lists in the Griscom study will be referred to as the Indiana lists and the lists from the current study as the national lists. In the lists of journals used in all disciplines of music, nineteen journals were included on both lists, and twenty-six appeared on one list only. Also, fifteen journal titles appeared on the national list that began publication too late to be available for the Indiana study. ${ }^{24}$

The results were similar when the core lists for the subcategories in music were compared. Eleven musicology journals were on both lists, but forty-one journals appeared on only one of the lists. The national list included thirteen journals that began publication too late to be included.

In music theory, only three journals were included on both lists. Six other journals were on the national list, and every one of them began publication too late to be included on the Indiana list. The Indiana lists included one journal that did not appear on the national list for music theory. The music education journal list 


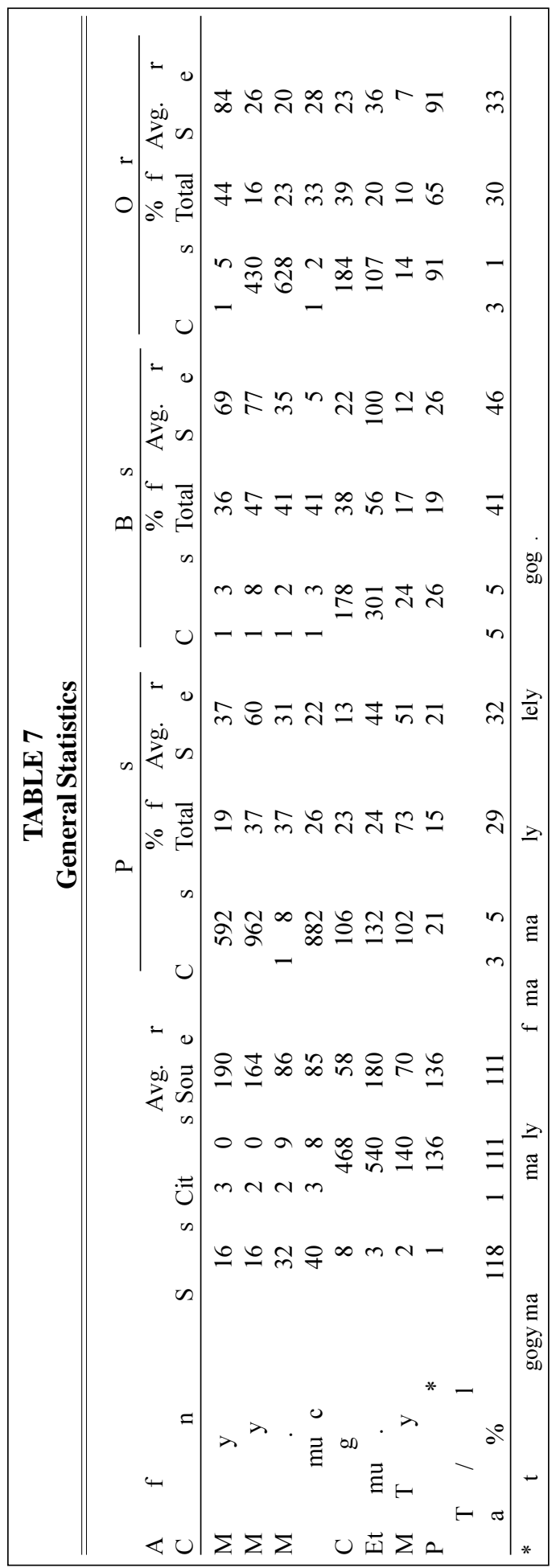

had four journals appearing on both lists. Fifteen journals were on either the national list or the Indiana list, but not on both. Three journals began publication too late to be included in the comparison.

These findings support the assertion made earlier in this article that a core list of journals developed by studying a single institution's dissertation citations may not reflect the needs of the user at either the institutional or the national level. If a list of journals developed by studying dissertations from a broad range of institutions is consulted, a journal collection can be developed that may be more reliable and less skewed by curricular or individual faculty needs at a particular institution. One also may determine, as seen in this study, which new journals are used most heavily and should be a part of the library's collection.

\section{Observations}

Many factors influence the inclusion or exclusion of any journal on lists of core journals in a subject. Most journals are included on lists such as this because they are used frequently by a majority of the user population, but some reach these lists due to a single user frequently citing a journal or several users coincidentally using journals in a single year. All these factors contribute to the inclusion of titles on a core list of journals and speak to the idiosyncratic nature of research. For example, an examination of the journal lists of the subcategories of music reveals some surprising titles, including Journal of the Historical Society of the Cocalico Valley on the musicology list and MIX on the music education list. What is important to note, however, is that when the citation counts of subdisciplines are combined into a general music list, the titles in the top 50 percent include few, if any, surprises. 


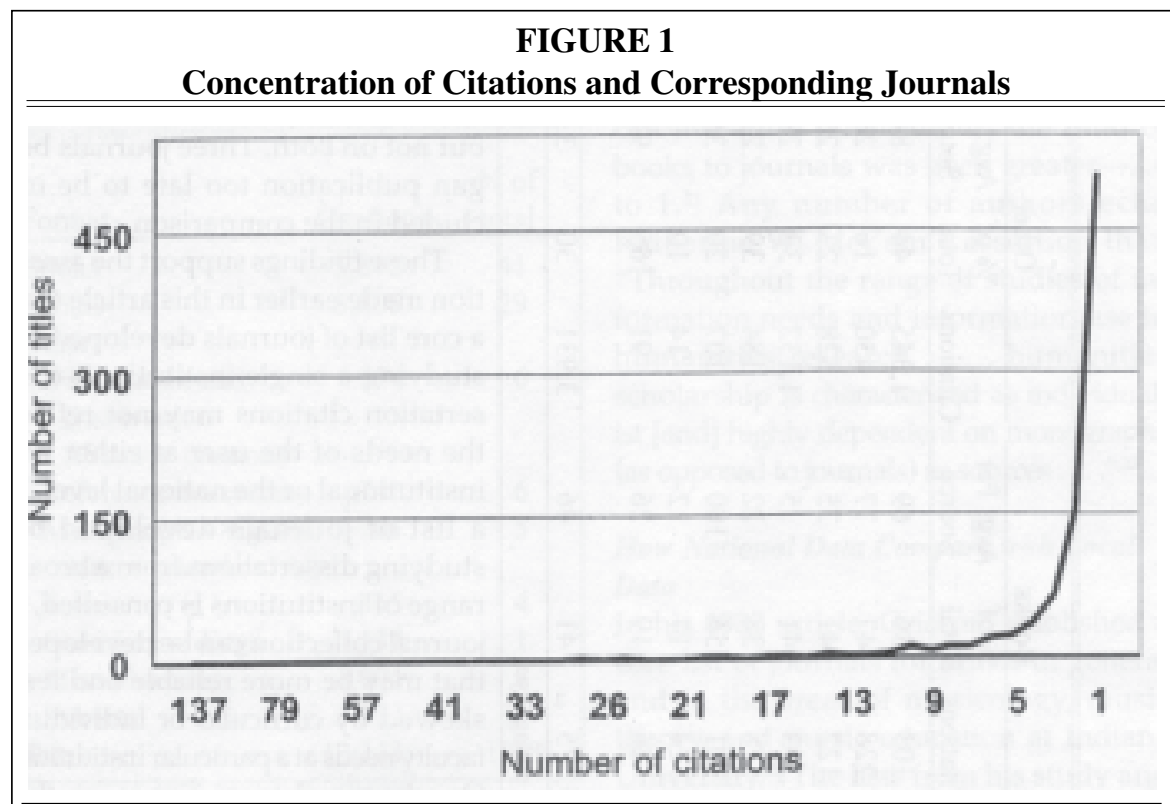

Only one ournal had $137,79,57$, etc., citations, but many had five or fewer citations, including more than 500 with only one.

The data on the citation of earlier dissertations in dissertation research are interesting. Use of previously written dissertations by doctoral students is not surprising, but what this investigator found fascinating is that of the 814 dissertation/ Dissertation Abstracts citations, 299 came from Dissertation Abstracts rather than from dissertations. Doctoral students and their advisors seem willing to accept the summary (abstract) of the dissertation as adequate information for citing in dissertations.

One surprising finding relates to the number of journals used for most citations in music dissertations. Of a total of 939 journals cited overall, 52 accounted for 50 percent of the journal citations; that is, 5.5 percent of all journals used produced 50 percent of all citations. Figure 1 provides a visual representation of the fact that a small number of journals are used much more heavily than all the rest of the journal literature cited in this study. This corresponds to Bradford's Law, a broad definition of which is: "for a search on some specific topic, a large number of the relevant articles will be concentrated in a small number of journal titles. The re- maining articles will be dispersed over a large number of titles." 25

The list that was compiled for doctoral students in music theory is brief when compared to the other subcategories. This is also true concerning the list that Griscom developed in 1983 for music theory. In this subcategory in the present study, 50 percent of all citations came from 4.7 percent of all music theory journals used in the study group, and 24.6 percent of these citations come from journals that were not even being published when the Griscom study was done.

\section{Conclusions}

This study focused on journal use by doctoral students in music. Its goal was to provide a tool that music bibliographers could use in evaluating an institution's current journal collection. The various core journal lists provided in tables 1 through 5 can be used for this purpose. If a music school's primary focus is in one area of music at the doctoral level, the journals listed in the corresponding table could be considered the most important for that institution. Although doctoral students make up only one segment of the 
music journal user population, it is a segment that relies heavily on periodical literature and often defines what is most needed in a journal collection in an academic library.

A further conclusion that can be drawn from this study is that journal literature in the field of music may be less static than once assumed. A large number of journals have begun publication since the 1970 s and already are crowding the list of most-cited journals. Music bibliographers must be cognizant of this fact and must be willing to devote time to review, and money to subscribe to, new journal publications. As more and more students and faculty are being recruited for doctoral programs, libraries must be willing to adjust their serials subscriptions to make music collections relevant to current doctoral programs.

\section{Notes}

1. Tina E. Chrzastowski and Karen A. Schmidt, "Surveying the Damage: Academic Library Serial Cancellations 1987-1988 through 1989," College and Research Libraries 54 (1993): 93-102.

2. _- "Collections at Risk: Revisiting Serial Cancellations in Academic Libraries," College and Research Libraries 57 (1996): 351-64.

3. Mary T. Kim, "Ranking of Journals in Library and Information Science: A Comparison of Perceptual and Citation-based Measures," College and Research Libraries 52 (1991): 24-37.

4. John Budd, "Faculty Publishing Productivity: An Institutional Analysis and Comparison with Library and Other Measures," College and Research Libraries 56 (1995): 547-54.

5. _— "Characteristics of Written Scholarship in American Literature: A Citation Study," Library and Information Science Research 8 (1986): 189.

6. Lois Bebout, Donald Davis Jr., and Donald Oehlerts, "User Studies in the Humanities: A Survey and a Proposal," RQ 15, no. 1 (1975): 40-44.

7. Carolyn Olivia Frost, "Use of Citations in Literary Research: An Analysis of Reference Citations in Publications about Literary Works Written in the German Language (Ph.D. diss., University of Chicago, 1977), Dissertation Abstracts International X1977.

8. John Budd, "A Citation Study of American Literature: Implications for Collection Management," Collection Management 8, no. 2 (1986): 49-62.

9. Barbara Kay Adams, "Collection Assessment and Development of a Core List of Periodicals in Southern Culture," Collection Management 16, no. 1 (1992): 103-16.

10. Jean-Pierre V. M. Herubel, "Philosophy Dissertation Bibliographies and Citations," Serials Librarian 20, no. 2-3 (1991): 65-73.

11. R. M. Longyear, "Article Citations and Obsolescence in Musicological Journals," Notes: The Quarterly Journal of the Music Library Association 33, no. 3 (1977): 563-71.

12. Richard Griscom, "Periodical Use in a University Music Library: A Citation Study of Theses and Dissertations Submitted to the Indiana University School of Music from 1975-1980," Serials Librarian 7, no. 3 (1983): 35-52.

13. Herubel, "Philosophy Dissertation Bibliographies and Citations," 65-73.

14. Margaret Sylvia and Marcella Lesher, "What Journals Do Psychology Graduate Students Need? A Citation Analysis of Thesis References," College and Research Libraries 56 (1995): 313-18.

15. Anne L. Buchanan and Jean-Pierre V. M. Herubel, "Profiling PhD Dissertation Bibliographies: Serials and Collection Development in Political Science," Behavioral E Social Sciences Librarian 13, no. 1 (1994): 1-10.

16. A doctorate in applied music is a degree in which the student studies the performance of music.

17. Of the dissertations by students concentrating on music composition that the author received, all but one were compositions by that student and thus had only original material and no citations. These were considered unusable dissertations for this study.

18. Griscom, "Periodical Use in a University Music Library," 35-52.

19. There were so few music therapy graduates in the pool that no valid conclusions can be drawn from the percentages seen here.

20. Ratios found by comparing Griscom's totals to totals from the present study.

21. Budd, "Characteristics of Written Scholarship in American Literature," 192.

22. Katherine W. McCain, "Citation Patterns in the History of Technology," Library and Information Science Research 9 (1987): 42.

23. Griscom, "Periodical Use in a University Music Library," 48-52.

24. Any journal that began publication after 1970 was not included.

25. M. Carl Drott, "Bradford's Law: Theory, Empiricism and the Gaps Between," Library Trends 30 (summer 1981): 41. 